\title{
Seasonal variations of water vapor in the lower stratosphere inferred from ATMOS/ATLAS-3 measurements of $\mathrm{H}_{2} \mathrm{O}$ and $\mathrm{CH}_{4}$
}

\author{
M. M. Abbas, ${ }^{1}$ H. A. Michelsen, ${ }^{2}$ M. R. Gunson, ${ }^{3}$ M. C. Abrams, ${ }^{4}$ M. J. Newchurch, ${ }^{5}$ \\ R. J. Salawitch, ${ }^{3}$ A. Y. Chang, ${ }^{3}$ A. Goldman, ${ }^{6}$ F. W. Irion, ${ }^{7}$ G. L. Manney, ${ }^{3}$ E. J. \\ Moyer, ${ }^{7}$ R. Nagaraju, ${ }^{5}$ C. P. Rinsland, ${ }^{4}$ G. P. Stiller, ${ }^{8}$ and R. Zander ${ }^{9}$
}

\begin{abstract}
Stratospheric measurements of $\mathrm{H}_{2} \mathrm{O}$ and $\mathrm{CH}_{4}$ by the Atmospheric Trace Molecule Spectroscopy (ATMOS) Fourier transform spectrometer on the ATLAS-3 shuttle flight in November 1994 have been examined to investigate the altitude and geographic variability of $\mathrm{H}_{2} \mathrm{O}$ and the quantity $\boldsymbol{H}=\left(\mathrm{H}_{2} \mathrm{O}+2 \mathrm{CH}_{4}\right)$ in the tropics and at mid-latitudes (8 to $49^{\circ} \mathrm{N}$ ) in the northern hemisphere. The measurements indicate an average value of $7.24 \pm 0.44 \mathrm{ppmv}$ for $\boldsymbol{H}$ between altitudes of about 18 to $35 \mathrm{~km}$, corresponding to an annual average water vapor mixing ratio of $3.85 \pm 0.29 \mathrm{ppmv}$ entering the stratosphere. The $\mathrm{H}_{2} \mathrm{O}$ vertical distribution in the tropics exhibits a wave-like structure in the $16-$ to $25-\mathrm{km}$ altitude range, suggestive of seasonal variations in the water vapor transported from the troposphere to the stratosphere. The hygropause appears to be nearly coincident with the tropopause at the time of observations. This is consistent with the phase of the seasonal cycle of $\mathrm{H}_{2} \mathrm{O}$ in the lower stratosphere, since the ATMOS observations were made in November when the $\mathrm{H}_{2} \mathrm{O}$ content of air injected into the stratosphere from the troposphere is decreasing from its seasonal peak in JulyAugust.
\end{abstract}

\section{Introduction}

The stratospheric water vapor distribution is determined by a combination of chemical and dynamical processes. Chemical processes involving the oxidation of $\mathrm{CH}_{4}$ enhance the abundance of $\mathrm{H}_{2} \mathrm{O}$, producing approximately two molecules of $\mathrm{H}_{2} \mathrm{O}$ for each molecule of $\mathrm{CH}_{4}$ and leading to higher $\mathrm{H}_{2} \mathrm{O}$ mixing ratios with altitude relative to air entering the stratosphere. Since $\mathrm{H}_{2} \mathrm{O}$ is a major source of the reactive odd hydrogen species, and is considered to be an important tracer of transport from the troposphere to the stratosphere, measurements of its

\footnotetext{
'NASA Marshall Space Flight Center.

${ }^{2}$ Harvard University.

3 Jet Propulsion Laboratory, California Institute of Technology.

${ }^{4}$ SAIC-NASA Langley Research Center.

${ }^{5}$ University of Alabama at Huntsville.

${ }^{6}$ Denver University.

${ }^{7}$ California Institute of Technology.

${ }^{k}$ Forschungszentrum Karlsruhe/Universitaet Karlsruhe.

${ }^{9}$ Institute of Astrophysics, University of Liege.
}

Copyright 1996 by the American Geophysical Union.

Paper number 96GL.01321

0094-8534/96/96GL-01321\$05.00 stratospheric distribution have been extensive and have been carried out with a variety of techniques including ground-based, and aircraft-, balloon-, and satellite-borne instruments [e.g., Hansen and Robinson, 1989; Gunson et al., 1990; McCormick et al., 1993; Oltmans and Hofmann, 1995].

The ATMOS/ATLAS-3 limb viewing solar occultation observations of stratospheric trace constituents provide simultaneous measurements of $\mathrm{H}_{2} \mathrm{O}$ and $\mathrm{CH}_{4}$ distributions over the 8 to $49^{\circ} \mathrm{N}$ and 67 to $72^{\circ} \mathrm{S}$ latitude ranges during November 3 to 12, 1994 [Gunson et al., 1996]. This paper focuses on a portion of the retrieved data for the $16-$ to $35-\mathrm{km}$ altitude range at northern mid-latitudes and tropics. We test the conservation of $\boldsymbol{H}=\left(\mathrm{H}_{2} \mathrm{O}+2 \mathrm{CH}_{4}\right)$, deduce the annual average $\mathrm{H}_{2} \mathrm{O}$ mixing ratio transported to the stratosphere, and examine profiles of $\mathrm{H}_{2} \mathrm{O}$ for evidence of seasonal variation of water vapor entering into the stratosphere.

\section{Methane Oxidation and the Hydrogen Budget of the Lower and Middle Stratosphere}

Methane is oxidized in the stratosphere mainly by reactions with $\mathrm{OH}$ and $\mathrm{O}\left({ }^{1} \mathrm{D}\right)$ and to a lesser extent $\mathrm{Cl}$. The net result of a series of reactions leads to formation of approximately two molecules of $\mathrm{H}_{2} \mathrm{O}$ for each molecule of $\mathrm{CH}_{4}$

$$
\mathrm{CH}_{4}+2 \mathrm{O}_{2} \rightarrow \mathrm{CO}_{2}+2 \mathrm{H}_{2} \mathrm{O} \text {. }
$$

In addition to $\mathrm{CH}_{4}$ and $\mathrm{H}_{2} \mathrm{O}, \mathrm{H}_{2}$ is the only other abundant hydrogen-containing species in the stratosphere. Available in situ balloon-borne/rocket measurements of molecular hydrogen in the stratosphere indicate nearly constant mixing ratio with altitude, in accordance with a near balance between production by methane oxidation and loss by oxidation of $\mathrm{H}_{2}$ [e.g., Ehhalt and Tonnisen, 1980; Brasseur and Solomon, 1986]. A major source of variability of $\mathrm{H}_{2} \mathrm{O}$ in the lower stratosphere is related to changes in $\mathrm{CH}_{4}$, owing to different photolytic histories of individual air masses. Simultaneous observations of $\mathrm{H}_{2} \mathrm{O}$ and $\mathrm{CH}_{4}$ enable us to assess whether changes in $\mathrm{H}_{2} \mathrm{O}$ are related to oxidation of $\mathrm{CH}_{4}$, or some other process, and recent ATMOS measurements in the $16-$ to $35-\mathrm{km}$ altitude range for a wide range of latitudes are examined to test our general understanding of the conservation of $\boldsymbol{H}$ and the hydrogen budget of the lower and middle stratosphere.

A correlation plot of $\mathrm{H}_{2} \mathrm{O}$ versus $\mathrm{CH}_{4}$ for 47 profiles in the 8 to $49^{\circ} \mathrm{N}$ latitude range is shown in Figure 1. The line represents an average linear fit to the measurements (closed symbols) over the 18 - to $35-\mathrm{km}$ range $\left(\mathrm{CH}_{4} \sim 0.5\right.$ to $\left.1.6 \mathrm{ppmv}\right)$ given by

$$
\left[\mathrm{H}_{2} \mathrm{O}\right]=(-1.99 \pm 0.04)\left[\mathrm{CH}_{4}\right]+7.24 \pm 0.04 \mathrm{ppmv},
$$

with the uncertainties representing the standard deviation of 


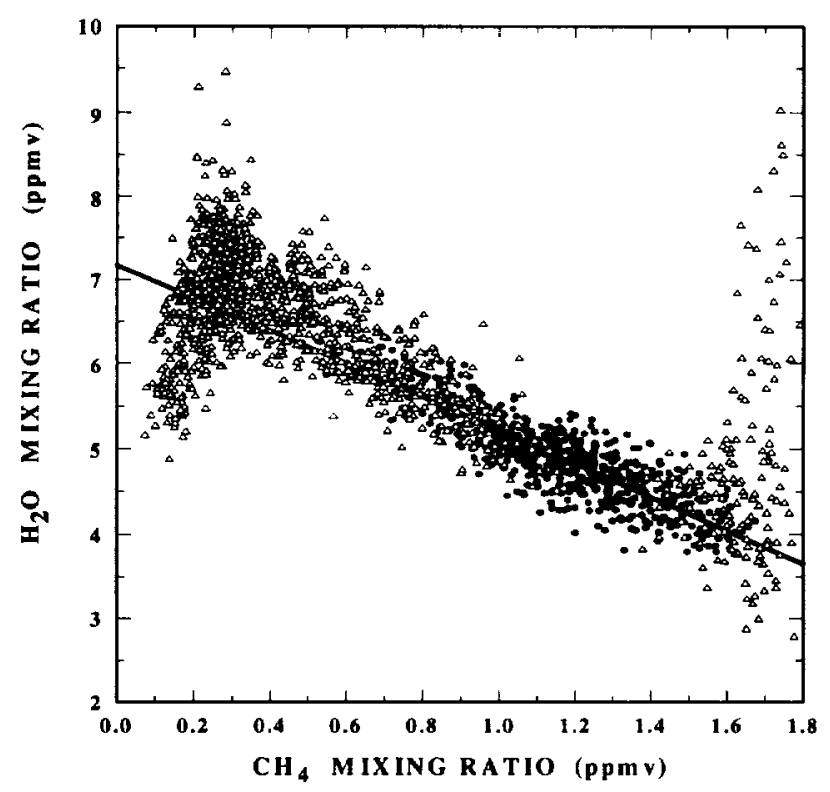

Figure 1. A scatter plot of ATMOS measurements of $\mathrm{H}_{2} \mathrm{O}$ versus $\mathrm{CH}_{4}$ for 47 sunset occultations in the 8 to $49^{\circ} \mathrm{N}$ latitude range. The solid line represents a least square fit (equations given in text) to data obtained over the 18 - to $35-\mathrm{km}$ altitude range $\left(\mathrm{CH}_{4}-0.6\right.$ to $\left.1.6 \mathrm{ppmv}\right)$.

the linear regression. The systematic uncertainty in the measurements of $\mathrm{H}_{2} \mathrm{O}$ and $\mathrm{CH}_{4}$ lead to total uncertainties of \pm 0.16 and $\pm 0.44 \mathrm{ppm} v$ in slope and intercept, respectively. The inferred slope $\partial \mathrm{H}_{2} \mathrm{O} / \partial \mathrm{CH}_{4} \cong-2$ implies that each $\mathrm{CH}_{4}$ molecule is converted into two molecules of $\mathrm{H}_{2} \mathrm{O}$, whereas the intercept $7.24 \pm 0.44$ indicates approximately the average $\boldsymbol{H}$ in the $18-$ to $35-\mathrm{km}$ region. A precise determination of this slope and its deviation from -2 is important because of its implication for the distribution of $\mathrm{H}_{2}$ in the stratosphere [Dessler et al., 1994; Abbas et al., 1996].

Observed mixing ratio of $\mathrm{H}_{2}$ by balloon-borne instruments suggest a small decrease with height in the $16-$ to $35-\mathrm{km}$ range, varying from $\sim 0.55 \mathrm{ppmv}$ at the tropopause to $\sim 0.5$ at $30 \mathrm{~km}$ [e.g., Ehhalt and Tonnisen, 1980]. Assuming conservation of $\boldsymbol{H}$ and $\mathrm{H}_{2}$, this would correspond to a slope $\partial \mathrm{H}_{2} \mathrm{O} / \partial \mathrm{CH}_{4}$ $\sim-2.06$. Dessler et al. [1994] inferred a value of $\partial \mathrm{H}_{2} \mathrm{O} / \partial \mathrm{CH}_{4}=$ $-1.94 \pm 0.27$ in the lower stratosphere from measurements on the ER-2 aircraft. The aircraft, balloon-borne, and ATMOS data in the 16- to $35-\mathrm{km}$ altitude range are all consistent statistically with conservation of $H$ and with a $\partial \mathrm{H}_{2} \mathrm{O} / \partial \mathrm{CH}_{4}$ of -2 . The distribution of $\boldsymbol{H}$ with altitude and its deviation from a constant value in the upper stratosphere and the mesosphere is discussed in another paper [Abbas et al., 1996].

Measurements of $\boldsymbol{H}$ by other experiments for comparison are: 6.0 ppmv from LIMS and SAMS data [Jones et al., 1986]; $7.0 \pm 0.6 \mathrm{ppm} v$ at $30 \mathrm{~km}$ from the ATMOS experiment on Spacelab 3 [Gunson et al., 1990]; $7.6 \pm 0.6$ ppmv from data collected on the ER-2 aircraft [Dessler et al., 1994]. It is unlikely that an atmospheric process could be responsible for the large differences in $\boldsymbol{H}$ observed by ATMOS and the combination of LIMS and SAMS. The Nimbus 7 satellite measurements of $\boldsymbol{H}$ have large systematic errors, as discussed by Hansen and Robinson [1989]. A small part of the difference between values of $\boldsymbol{H}$ measured by the present ATMOS observations and the ATMOS data for April 1985 reported by Gunson et al. [1990] may be accounted for by long-term increases in $\mathrm{H}_{2} \mathrm{O}$ and $\mathrm{CH}_{4}$ [Oltmans and Hofmann, 1995; WMO, 1995].
Differences in the determination of $\boldsymbol{H}$ based on the present ATMOS observations and the in situ data reported by Dessler et al. [1994] lie within the systematic uncertainties of both sets of measurements, although the ATMOS value is lower by about 0.4 ppmv. A comparison of ATMOS observations of $\mathrm{H}_{2} \mathrm{O}$, $\mathrm{CH}_{4}$, and $\mathrm{N}_{2} \mathrm{O}$ with nearly coincident in situ measurements obtained in the lower stratosphere during November 1994 shows excellent agreement for each species, yielding virtually identical values of $\boldsymbol{H}$ [Chang et al., 1996]. For the November 1994 coincidence, the only available in situ measurements of $\mathrm{H}_{2} \mathrm{O}$ and $\mathrm{CH}_{4}$ were obtained by the NOAA Lyman $\alpha$ hygrometer and the NOAA Airborne Chromatograph for Atmospheric Trace Species (ACATS) gas chromatograph, respectively. Dessler et al.'s [1994] estimate of $H$ was based on observations of $\mathrm{H}_{2} \mathrm{O}$ and $\mathrm{CH}_{4}$ from the Harvard Lyman $\alpha$ hygrometer and the Aircraft Laser Infrared Absorption Spectrometer (ALIAS) instrument, respectively. During May 1993, measurements of $\mathrm{H}_{2} \mathrm{O}$ by the Harvard hygrometer exceeded those obtained by the NOAA instrument by $\sim 15 \%$ [Hintsa et al., 1994], and measurements of $\mathrm{CH}_{4}$ by ALIAS were $-10 \%$ lower than measurements by ACATS [Dessler et al., 1994]. Consequently, the lower value of $\boldsymbol{H}$ measured by ATMOS relative to the in situ determination of Dessler et al. [1994] may be primarily due to systematic differences in the measurement of $\mathrm{H}_{2} \mathrm{O}$, offset slightly by the differences in observations of $\mathrm{CH}_{4}$.

The value of $\boldsymbol{H}$ is important for assessing the average mixing ratio of $\mathrm{H}_{2} \mathrm{O}$ injected from the troposphere into the stratosphere. Our estimate for the annual average amount of $\mathrm{H}_{2} \mathrm{O}$ entering the stratosphere is based on least square fits to ATMOS measurements of $\mathrm{H}_{2} \mathrm{O}$ and $\mathrm{CH}_{4}$ collected over a wide range of altitudes, rather than observations at the tropopause, to reduce the sensitivity of our result to seasonal and episodic variations in $\mathrm{H}_{2} \mathrm{O}$. ATMOS observations used in the fit were obtained in the 18 - to $35-\mathrm{km}$ altitude range, representing an average over a period of $\sim 18$ months, assuming upward velocities of $\sim 7$ to $8 \mathrm{~km}$ per year (see discussion below). Since tropo-

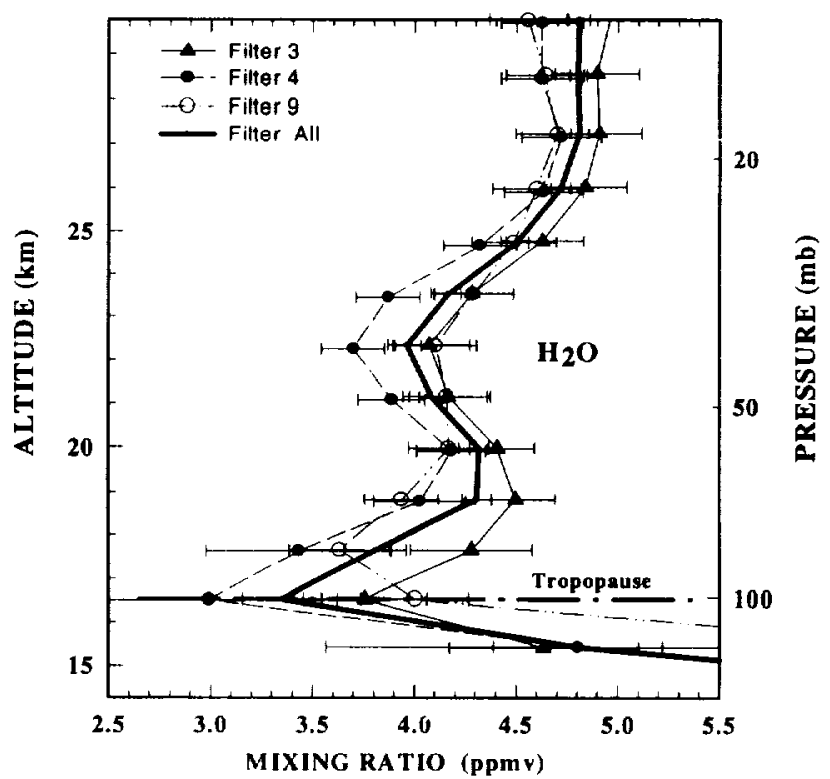

Figure 2. Average profiles of $\mathrm{H}_{2} \mathrm{O}$ in the tropics data obtained by filters 3,4 , and 9 separately, and an average of profiles obtained using all filters for latitude range of $81028^{\circ} \mathrm{N}$. The tropopause height, as determined from the National Meteorological Center data, is indicated by the horizontal line. 
spheric methane has small seasonal variations $(\sim 3 \%)$, we assume a constant mixing ratio of $1.70 \mathrm{ppmv}$ for $\mathrm{CH}_{4}$ for air entering the stratosphere. This leads to an annually averaged $\mathrm{H}_{2} \mathrm{O}$ mixing ratio of $3.84 \pm 0.29$ ppmv for air injected into the stratosphere.

Previous in situ and satellite observations of this quantity are: Remsberg et al. [1995] estimated an annual average value in the range of 3.2 to $3.7 \mathrm{ppmv}$ the HALOE data; Dessler et al. [1994] determined a value of $4.2 \pm 0.5 \mathrm{ppmv}$ from ER-2 data; Hansen and Robinson [1989] reported 3.25 ppmv from LIMS/SAMS data; while Jones et al. [1986] reported $2.7 \mathrm{ppmv}$ from an earlier analysis of the same satellite data. We note again the possibility of large systematic errors that have not been fully quantified in the LIMS/SAMS data [Hansen and Robinson, 1989]. The discrepancy between ATMOS and in situ estimates of $\mathrm{H}_{2} \mathrm{O}$ entering the stratosphere lies with the systematic uncertainty of both sets of measurements. The in situ estimate, although based on measurements over the 17- to 20 . $\mathrm{km}$ altitude range, included a wide range of $\mathrm{CH}_{4}$ mixing ratios ( 0.9 to 1.5 ppmv) and should have a minor sensitivity to seasonal variations in $\mathrm{H}_{2} \mathrm{O}$. Systematic differences between measurements of $\mathrm{H}_{2} \mathrm{O}$ and $\mathrm{CH}_{4}$ obtained by ATMOS and the in situ observations of Dessler et al. [1994] may be primarily responsible for the offset.

\section{Seasonal Variations in Water Vapor}

Since observations of the hygropause (a minimum in the stratospheric water vapor mixing ratio) by Kley et al. in 1979 . the nature and mechanism of its formation have been the subject of active discussion in the literature. The amount of water vapor entering the stratosphere may be influenced by temperatures at the tropopause and within upper troposphere. With the injection limited to the tropical regions, the hygropause altitude was expected to be coincident with the tropopause at tropical latitudes. Numerous measurements have indicated the hygropause to be located above the tropopause by 2 to $3 \mathrm{~km}$ [e.g., Russell et al., 1984; Jones et al., 1986; Kelly et al., 1989, 1993]. The tropical tropopause in the northern hemisphere has a maximum monthly mean temperature in the sum-

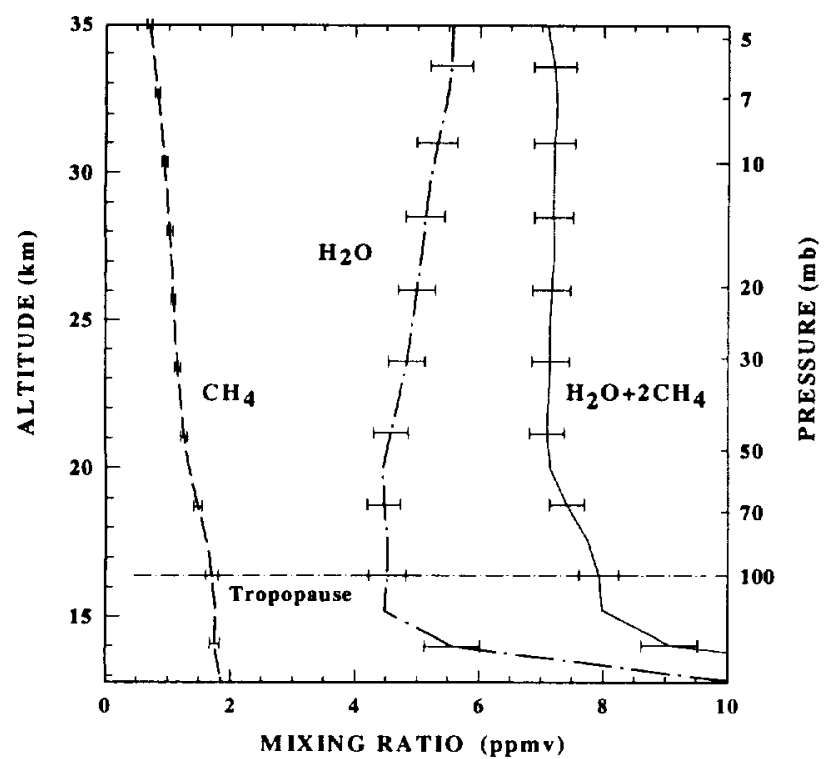

Figure 3. The vertical profiles of $\mathrm{CH}_{4}, \mathrm{H}_{2} \mathrm{O}$, and $\mathrm{H}=\left(\mathrm{H}_{2} \mathrm{O}+2 \mathrm{CH}_{4}\right)$ from a zonal average of 27 sunset occultations for midlatitudes in the latitude 32 to $49^{\prime \prime} \mathrm{N}$ range. The tropopause height, as determined from the National Meteorological Center data, is indicated by the horizontal line.

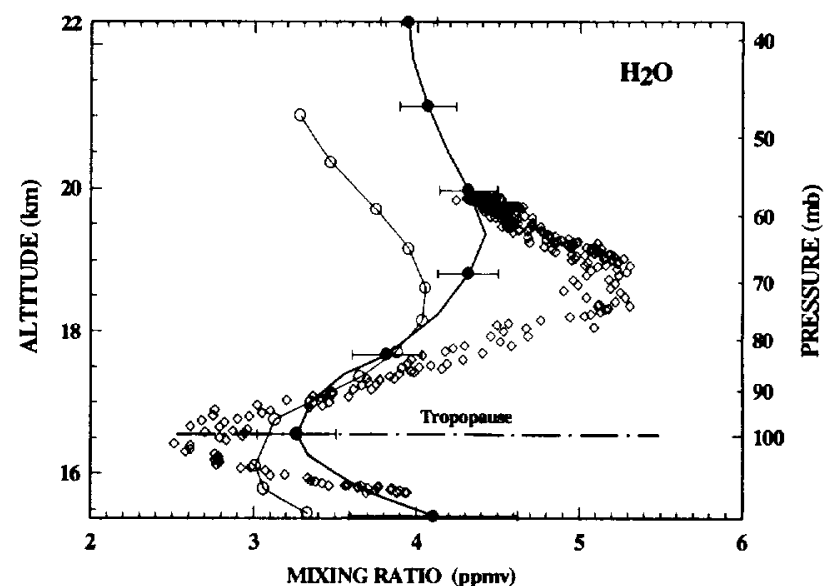

Figure 4. Comparison of the average profile of $\mathrm{H}_{2} \mathrm{O}$ retrieved from 18 sunset occultations by ATMOS in the 8 to $28^{\circ} \mathrm{N}$ latitude range on November 3 to 12, 1994, (filled circles) with: NOAA Lyman- $\alpha$ hygrometer measurements (diamonds) over $2^{\circ} \mathrm{S}$ to $2^{\circ} \mathrm{N}$ latitudes made on ER-2 aircraft on October 29, 1994 [K. Kelly, private communication]; average of HALOE measurements (open circles) over $5^{n} \mathrm{~S}$ to $5^{\circ} \mathrm{N}$ latitudes made on November 1 to 13. 1994 [Mote et al., 1996].

mer and occurs at a lower altitude, and has a minimum mean temperature in the winter occurring at a higher altitude. The variation in tropopause temperature from summer to winter is $\sim 5 \mathrm{~K}$, with a change in altitude of $\sim 1 \mathrm{~km}$ [e. g., Reid and Gage, 1981]. Several recent measurements at both tropical and middle latitudes have provided convincing evidence of seasonal variations in lower stratospheric water vapor, in phase with changes in annual tropopause temperatures [McCormick, 1993; Hintsa et al., 1994; Boering et al., 1995; Mote et al., 1995].

The simultaneous ATMOS measurements of $\mathrm{H}_{2} \mathrm{O}$ and $\mathrm{CH}_{4}$ made during the ATLAS-3 mission in November 1994 are examined for a record of seasonal variations of $\mathrm{H}_{2} \mathrm{O}$ entry into the stratosphere. The vertical profiles of $\mathrm{H}_{2} \mathrm{O}$ retrieved from a single occultation exhibit periodic structures of \pm 3 to $4 \%$ arising from random errors in the retrieval process which may be due to tangent pressure/altitude assignments for the limb-viewing geometry. This structure, however, is largely smoothed out when averaged over a sufficient number of occultations. In addition, there are systematic differences between the results obtained from the three different optical bandpass filters employed in the observations. To show this variability, we plot in Figure 2 the profiles of $\mathrm{H}_{2} \mathrm{O}$ retrieved from data obtained during November 3 to 12, 1994, from three different optical band-pass filters, zonally averaged over: (i) nine occultations $\left(8\right.$ to $\left.28^{\circ} \mathrm{N}\right)$, with filter 3 in the $1580-3340 \mathrm{~cm}^{-1}$ region, (ii) four occultations $\left(9\right.$ to $22^{\circ} \mathrm{N}$ ), with filter 4 in the $3150-4800 \mathrm{~cm}^{-1}$ region, (iii) five occultations (12 to $26^{\circ} \mathrm{N}$ ), with filter 9 in the 600 to $2,450 \mathrm{~cm}^{-1}$ region, and (iv) 18 occultations $\left(8\right.$ to $28^{\circ} \mathrm{N}$ ) using data from all filters. The error bars shown are the quadrature sum of the weighted standard deviation of the mean and systematic spectral errors of $\pm 6 \%$. The tropopause height indicated in Figure 2 (and all subsequent figures) is based on an analysis of NMC temperature profiles for the relevant region.

The tropical $\mathrm{H}_{2} \mathrm{O}$ profiles exhibit characteristic features with two minima occurring at $\sim 16.5 \mathrm{~km}$ and $22.5 \mathrm{~km}$, a maximum at $\sim 19.0 \mathrm{~km}$, and a weak maximum $\sim 27 \mathrm{~km}$. These features are suggestive of seasonal variations in the $\mathrm{H}_{2} \mathrm{O}$ entry into the stratosphere; simultaneous measurements of profiles of $\mathrm{CH}_{4}$ (not shown) are relatively featureless, demonstrating that the variability in profiles of $\mathrm{H}_{2} \mathrm{O}$ does not originate from oxida- 
tion of $\mathrm{CH}_{4}$. Seasonal variations in $\mathrm{H}_{2} \mathrm{O}$ at lower stratospheric altitudes below $-19 \mathrm{~km}$ have also been observed by SAGE II [Rind et al., 1993], HALOE and MLS [Mote et al., 1995], and instruments aboard the ER-2 aircraft [Boering et al., 1995]. The average profiles of $\mathrm{H}_{2} \mathrm{O}, \mathrm{CH}_{4}$, and $\boldsymbol{H}$ obtained from 33 occultations at a mean value of $\sim 42^{\circ} \mathrm{N}$ are shown in Figure 3 . The $\mathrm{H}_{2} \mathrm{O}$ profile is relatively featureless above $-19 \mathrm{~km}$, with mixing ratio increasing from a minimum of $4.5 \mathrm{ppmv}$ at the tropopause to about $5.6 \mathrm{ppmr}$ at $35 \mathrm{~km}$. By the time air reaches the mid-latitude region from the tropics, seasonal variations in $\mathrm{H}_{2} \mathrm{O}$ appear to have smoothed out. Figure 4 shows a comparison of the average $\mathrm{H}_{2} \mathrm{O}$ profile of Figure 2 (mean latitude $\sim 42^{\circ} \mathrm{N}$ ) with the results obtained from near simultaneous observations by the HALOE solar occultation experiment on UARS made during November 1 to 13,1994, in the $5^{\circ} \mathrm{S}$ to $5^{\circ} \mathrm{N}$ latitude range [Mote et al., 1995], and the NOAA Lyman $\alpha$ hygrometer measurements obtained on ER-2 aircraft on October 29,1994 , from $2.2^{\circ} \mathrm{S}$ to $2.2^{\circ} \mathrm{N}[K$. Kelly, private communication]. Considering the $0.2-\mathrm{km}$ vertical resolution of the ER-2 measurements relative to the ATMOS field-of-view of $\sim 1.5$ to $2 \mathrm{~km}$, Figure 4 shows good agreement at lower altitudes between ATMOS, HALOE, and in situ measurements of $\mathrm{H}_{2} \mathrm{O}$. The discrepancy between ATMOS and HALOE measurements of $\mathrm{H}_{2} \mathrm{O}$ mixing ratios at higher altitudes could be partly due to latitudinal differences.

In view of seasonal variations in the water vapor entry into the stratosphere with a minimum in January and maximum in July [e.g., Rind et al., 1993; Boering et al., 1995; Mote et al., 1995], a close examination of ATMOS profiles of $\mathrm{H}_{2} \mathrm{O}$ leads to the following conclusions:

(i) The minimum mixing ratio of $\mathrm{H}_{2} \mathrm{O}$ shown in Figures 2 to 4 is coincident with the tropopause within the uncertainty of the field-of-view of ATMOS (with the exception of filter 9 measurements), consistent with the phase of the seasonal cycle, i.e., decreasing water vapor entry in November during the observational period; a separation of the hygropause from the tropopause would be expected in observations obtained a month or two after the minimum water vapor entry in JanuaryFebruary to a month or two after the maximum in July-August.

(ii) Assuming that the local maximum in the mixing ratio of $\mathrm{H}_{2} \mathrm{O}$ at $19 \mathrm{~km}$ represents the upward transport of air that entered the stratosphere in July 1994 and the local minimum at $22.5 \mathrm{~km}$ reflects entry in January 1994, the inferred annually averaged vertical velocity is estimated to be $\sim 7$ to $8 \mathrm{~km} /$ year $\left(2.4 \times 10^{-2} \mathrm{~cm} \mathrm{~s}^{-1}\right)$ near $22 \mathrm{~km}$. This analysis strongly suggests that ATMOS measurements of $\mathrm{H}_{2} \mathrm{O}$ and $\mathrm{CH}_{4}$ are consistent with water vapor entry into the stratosphere in all seasons and air with minimum $\mathrm{H}_{2} \mathrm{O}$ mixing ratio enters in the winter (January-February) in the northern hemisphere and maximum in the summer (July-August).

\section{Conclusions}

An examination of the simultaneous measurements of $\mathrm{H}_{2} \mathrm{O}$ and $\mathrm{CH}_{4}$ made by ATMOS/ATLAS-3 indicates near conservation of the quantity $\boldsymbol{H}=\left(\mathrm{H}_{2} \mathrm{O}+2 \mathrm{CH}_{4}\right)$ below altitudes of about $35 \mathrm{~km}$ at midlatitudes. The data indicate that air enters the stratosphere with an average $\mathrm{H}_{2} \mathrm{O}$ mixing ratio of $\sim 3.84 \pm$ 0.29 ppmv. Vertical structure in averaged tropical profiles of $\mathrm{H}_{2} \mathrm{O}$ suggests seasonal variations in the mixing ratio of $\mathrm{H}_{2} \mathrm{O}$ for air entering the stratosphere, and an average velocity of $\sim 7$ to $8 \mathrm{~km} /$ year in the lower stratosphere. The hygropause is observed to be within $\sim 2 \mathrm{~km}$ of the tropopause at tropical latitudes and is expected to be above the tropopause only when observed in the January-February to July-August period, when the $\mathrm{H}_{2} \mathrm{O}$ content of the air entering the stratosphere reaches its seasonal maximum.
Acknowledgment. Research at the Jet Propulsion Laboratory, California Institute of Technology was performed under contract to the National Aeronautics and Space Administration.

\section{References}

Abbas M. M., et al., The hydrogen budget of the stratosphere inferred from ATMOS measurements of $\mathrm{H}_{2} \mathrm{O}$ and $\mathrm{CH}_{4}$, this issue.

Bithell, M., et al. Synoptic interpretation of measurements from HALOE, J. Atmos. Sci., 5I, 2942-2956, 1994.

Boering, K. A., et al., Measurements of stratospheric carbon dioxide and water vapor at northern midlatitudes: Implications for troposphere to stratosphere transport, Geophys. Res. Lerf., submitted for publication, 1995.

Brasseur, G., and S. Solomon, Aeronomy of the Middle Atmosphere, D. Reidel Publishing, Holland, 1986.

Carr, E. S., et al., Tropical stratospheric water vapor measured by the microwave limb sounder (MLS), Geophys. Res. Lett., 22, 691-694, 1995.

Chang, A. Y., et al, A comparison of ATMOS and ER-2 measurements from ASHOE/MAESA: Reactive species, this issue

Dessler, A. E., et al., An examination of the total hydrogen budget of the lower stratosphere, 21, 2563-2566, 1994.

Ehhalt, D. H, and A. Tonnisen, Hydrogen and carbon compound in the stratosphere, 129-151, in Proc. NATO Advan. Study lnst. on Atmos. Ozone, eds., M Nicolet and A. C. Aikin, U. S. Dept of Transportation, Washington, D. C., 1980.

Gunson, M. R., et al., Measurements of $\mathrm{CH}_{4}, \mathrm{~N}_{2} \mathrm{O}, \mathrm{CO}, \mathrm{H}_{2} \mathrm{O}$, and $\mathrm{O}_{3}$ in the middle atmosphere by the Atmospheric Trace Molecule Spectroscopy experiment on Spacelab 3, J. Geophys. Res., 95. $13,867-13,882,1990$.

Gunson, M. R, et al., The Atmospheric Trace Molecule Spectroscopy experiment deployment on the ATLAS-3 space shuttle mission, this issue.

Hansen A. R., and G. D. Robinson, Water vapor and methane in the upper stratosphere: An examination of some of the Nimbus measurements, J. Geophys. Res., 94, 8474-8484, 1989.

Hintsa, E.J., et al., SPADE $\mathrm{H}_{2} \mathrm{O}$ measurements and the seasonal cycle of stratospheric water vapor, Geophys. Res. Lett., 21, 2559-2562, 1994.

Jones, R.L., et al., The water vapor budget of the stratosphere studied using LIMS and the SAMS satellite data, Q.J.R. Meteorol. Soc., I/2, 1127-1143, 1986.

Kelly, K.K., et al., Dehydration in the lower Antarctic stratosphere during the winter and the early spring, 1987, J. Geophys. Res., 94, 11,317-11,357, 1989.

Kelly, K.K., et al, Water vapor and cloud measurements over Darwin during the STEP 1987 tropical mission, J. Geophys. Res., 98. 8713-8723, 1993.

Kley, D., et al., In situ measurements of the mixing ratio of the water vapor in the stratosphere, J. Atmos. Sci., 36, 2513-2534, 1979.

McCormick, M. P., et al. Annual variations of water vapor in the stratosphere and upper stratosphere observed by the stratospheric aerosol and gas experiment II, J. Geophys. Res., 98, 4867-4874, 1993.

Mote P. M., et al., An atmospheric tape recorder: The imprint of tropical tropopause temperature on stratospheric water vapor, J. Geophys. Res., submitted for publication, 1995.

Oltmans, S. J., and D. J, Hofmann, Increase in lower-stratospheric wate vapor at a mid-latitude northern hemisphere site from 1981 to 1994 , Nature, 374, 146-149, 1995.

Reid, G. C., and K. Gage, On the annual variation of the tropical tropopause, J. Atmos. Sci., 38, 1928-1938, 1981

Remsberg, E. E., P. P. Bhatt, and J. M. Russell III, Estimates of water vapor budget of the stratosphere from UARS HALOE data, $l$. Geophys. Res., in press, 1995.

Rind, D., et al., Overview of the stratospheric acrosol gas experiment II water vapor observations: Method, validation, and data characteristics, J. Geophys. Res., 98, 4835-4856, 1993.

WMO. Scientific Assessment of Ozone Depletion: 1994, World Meteorological Organization, Global Ozone Research and Monitoring Project - No. 37. 1995.

M. M. Abbas. Mail Code ES41, Space Sciences Laboratory, NASA Marshall Space Flight Center, AL 35812. (e-mail:mian.abbas@msfc. nasa.gov)

(Received October 17, 1995; revised January 24, 1996; accepted March 26, 1996.) 